\title{
Maternal Nutrition Status are Strongly Associated to Schoolchildren Z-Scores for Height and BMI in Rural Settings
}

\author{
Dudung Angkasa $^{1 *}$, Nadiyah Nadiyah ${ }^{1}$ \\ 1- Department of Nutrition, Faculty of Health Sciences, Universitas Esa Unggul, Jakarta, Indonesia
}

\section{A B S T R A C T}

Background and Objectives: Parental factors, including social and anthropometric factors, play a vital role in children longterm nutritional status. The objective of this study was to investigate correlations between parental factors and nutritional status of the schoolchildren in a rural setting of Indonesia.

Materials and Methods: This cross-sectional study was carried out during May 2018. Totally, 146 schoolchildren from ten primary public schools in Sepatan Timur, Tangerang, Indonesia, were involved in the study. Structured questionnaires were used to collect socio-demographic data (educational level, employment status and number of children) and estimated anthropometric measures (body weight and height). Digital weighing scales and standard microtoises were used to measure children weight and height, respectively. Anthropometric indices, height for age (HAZ) and body mass index for age (BAZ) Z-scores were calculated using WHO AntroPlus. Moreover, multiple regression analysis was used in the study.

Results: Nearly 19.2, 11.6 and $16.4 \%$ of the schoolchildren were stunting, wasted and overweight, respectively. Maternal nutrition status were significantly associated with schoolchildren HAZ ( $\beta 95 \% \mathrm{CI}=0.367$ [0.009-0.724]) and BAZ ( $\beta$ $95 \% \mathrm{CI}=0.926[0.428-1.423]$ ) scores. The BAZ scores of the children were inversely associated with maternal education levels $(\beta 95 \% \mathrm{CI}=-1.206[-2.000 ;-0.441])$. Paternal nutrition status were significantly associated with children HAZ ( $\beta$ $95 \% \mathrm{CI}=0.419[0.075 ; 0.762])$ scores.

Conclusions: Parental anthropometric measure and educational status significantly contribute to development of schoolchildren nutritional status in the rural setting.

Keywords: Social factor, Anthropometric factor, Schoolchildren, Nutritional status, Rural setting

\section{Introduction}

National Nutritional Status Survey (1) (2017) reported a lower prevalence of stunting (27.2\%) and thinness $(10.9 \%)$ within Indonesian children aged 512 years old compared to that the previous national survey did (stunting 30.7\% and thinness $11.2 \%$ ) (2). Based on the public health cutoffs, the prevalence of stunting was classified as medium (20-29\%) (3). Schoolchildren with malnutrition (stunting, thinness) may perform poorly in classroom activities (4), experience impaired immune system responses and reduced physical growth potencies (5). Nowadays, researchers investigate causes of nutritional problems, especially those that can be solved by means of sensitive nutritional interventions. Sensitive nutritional interventions are linked to indirect factors (such as parents educational level, parenting style and other socio-demographic characteristics) that lead to wider consequences in tackling malnutrition (6). However, different setting areas (rural against urban, developing against developed) may result in different determinant factors of the children nutritional status (7-10). Studies in rural settings reported that parents educational level and employment were associated to children nutritional status $(11,12)$. Other studies found that parental anthropometric and socioeconomic factors were associated to children nutritional status $(13,14)$ in similar settings. The current study was carried out in a rural setting of Banten Province, Indonesia, to investigate 
correlations between parental social and anthropometric factors and schoolchildren nutritional status. Eventually, investigation of the parental social and anthropometric factors and their correlation with schoolchildren nutritional status is suggested.

\section{Materials and Methods}

This cross-sectional study derived from the baseline survey of an umbrella study entitled "The Effect of School Nutrition and Health Education (GISEL) and Its Report Administration to Parent on Children Weight in Rural Area of Tangerang Region". The baseline survey was carried out during May 4-15, 2018, purposively in ten out of 18 public elementary schools located in Sepatan Timur Subdistrict, District of Tangerang, Banten Province, Indonesia. Using G*Power Sample Size Calculator for the survey with $95 \%$ confidence level, $5 \%$ precision, $5 \%$ nonresponse rate and an effect size of 0.20 , a minimum sample size of 134 were calculated. Samples included schoolchildren aged 10-13 years old from $4^{\text {th }}$ and $5^{\text {th }}$ grades. They were selected purposively by considering the representative number of students of each class at the selected schools. Children who did not return the consent forms, had a physical disability or suffered from a severe infectious disease such as tuberculosis were excluded from the study. Parental socio-demographic factors were assessed using a structured questionnaire provided to all parents. The questionnaire included questions on parental education level, employment status and number of children. All parents were asked to best estimate their current weight and height. Parental body mass index (BMI) was calculated by dividing weight to square of their height (in meters). Results were classified as underweight (BMI $<18.5 \mathrm{~kg} / \mathrm{m}^{2}$ ), normal weight $\left(18.5-22.5 \mathrm{~kg} / \mathrm{m}^{2}\right)$ and overweight $\left(\right.$ BMI $\left.>22.5 \mathrm{~kg} / \mathrm{m}^{2}\right)$ (2). Children nutritional status was determined by actual measures of their weight and height. Trained personnel measured the children weight and height using digital weighing scales and standard microtoises, respectively. Anthropometric indices of height for age (HAZ) and body mass index for age (BAZ) were calculated using WHO AnthroPlus Software (15). Children with HAZ scores below -2.0 were classified as stunting, those with BAZ scores of -2.0 as wasted and those with BAZ scores above 1.0 as overweight (15). Furthermore, multiple regression analysis was used in this study. The current study received an ethical approval from the Ethical Committee of Health Sciences Faculty, Esa Unggul University, No. 0173-18.148/DPKEKEP/FINAL-EA/UEU/IV/2018. Permissions were received from the local authority (Tangerang District) and district health offices at Tangerang, Kedaung Barat Public Health Center and involved schools.

\section{Results}

Totally, 146 pairs of school-age children and parents were involved in the analysis. Parental characteristics of sociodemographic and nutritional status are shown in Table 1 and reported as $n(\%)$. More than half of the parents aged above 35 years old. Most parents did not complete the national minimum educational level (nine years of schooling) and the percentage of mothers with low educational levels $(83.6 \%)$ was higher than that of fathers with low educational levels (69.9\%). Most of the mothers did not work while most of the fathers did. Based on the nutritional status, both mothers and fathers were dominantly overweighed with the percentage of overweight mothers was higher than that of overweight fathers. Table 2 describes students' characteristics and nutritional status. The mean children age included nine years old, ranging 9.710.2. Nearly, $19.2,11.6$ and $16.4 \%$ of the children experienced stunting, wasted and overweight circumstances, respectively. Using multivariable analysis, no correlations were found between sociodemographic factors and children HAZ scores after adjustment with other potential confounding factors, including maternal age, educational level, employment status, paternal age, educational level and number of children. Parents BMIs were positively correlated with children HAZ scores. Schoolchildren whose fathers BMI were > 22.5 $\mathrm{kg} / \mathrm{m}^{2}$ (overweighed) had $0.427 \mathrm{HAZ}$ score higher than that children with fathers BMI of normal or underweight had. A similar correlation was seen between the mothers BMI and children HAZ scores, but the decrease value was only 0.383 higher in children of overweight mothers, compared to that in children of normal/underweight mothers. Interestingly, maternal education level and BMI were 
significantly correlated with the children BAZ scores. Children whose mothers schooling years were $<9$ had $0.753 \mathrm{HAZ}$ score lower than that children with mothers schooling years of $>9$ years had. Overweight mothers might increase their children BAZ scores by 0.926 point, compared to children with normal/underweight mothers.

Table 1. Parental characteristics and nutritional status ${ }^{1}$ $(n=146)$

\begin{tabular}{|c|c|}
\hline Variable(s) & $n(\%)$ \\
\hline \multicolumn{2}{|c|}{ Socio demographic factors } \\
\hline $\begin{array}{l}\text { Maternal age, years } \\
\begin{array}{l}21-35 \\
>35\end{array}\end{array}$ & $\begin{array}{l}35.4(31.7-39.1)^{2} \\
68(46.6) \\
78(53.4)\end{array}$ \\
\hline $\begin{array}{l}\text { Maternal educational } 1 \\
\quad<9 \\
\quad \geq 9\end{array}$ & $\begin{array}{l}122(83.6) \\
24(16.4)\end{array}$ \\
\hline $\begin{array}{l}\text { Maternal employment } \\
\text { Not working } \\
\text { Working }\end{array}$ & $\begin{array}{l}123(84.2) \\
23(15.8)\end{array}$ \\
\hline $\begin{array}{l}\text { Paternal age, years } \\
\begin{array}{l}21-35 \\
>35\end{array}\end{array}$ & $\begin{array}{l}39(35.4-44.7)^{5} \\
31(21.2) \\
115(78.8)\end{array}$ \\
\hline $\begin{array}{l}\text { Paternal educational le } \\
\quad<9 \\
\quad \geq 9\end{array}$ & $\begin{array}{l}102(69.9) \\
44(30.1)\end{array}$ \\
\hline $\begin{array}{l}\text { Paternal employment } \\
\text { Not working } \\
\text { Working }\end{array}$ & $\begin{array}{l}4(2.7) \\
142(97.3)\end{array}$ \\
\hline $\begin{array}{l}\text { Number of children } \\
\qquad \begin{array}{l}\leq 3 \\
>3\end{array}\end{array}$ & $\begin{array}{l}110(75.3) \\
36(24.7)\end{array}$ \\
\hline Parental anthropometr & \\
\hline Maternal weight, $\mathrm{kg}$ & $60(50-65)^{3}$ \\
\hline $\begin{array}{l}\text { Maternal height, } \mathrm{cm} \\
\quad<150.1 \\
\geq 150.1\end{array}$ & $\begin{array}{l}155(150-160) \\
58(39.7) \\
88(60.3)\end{array}$ \\
\hline $\begin{array}{c}\text { Maternal BMI, } \mathrm{kg} / \mathrm{m}^{2} \\
<18.5 \\
18.5-22.5 \\
>22.5\end{array}$ & $\begin{array}{l}24.4(21.3-27.0)^{4} \\
12(8.1) \\
40(27.4) \\
94(64.4)\end{array}$ \\
\hline Paternal weight, $\mathrm{kg}$ & $60(54-68)^{6}$ \\
\hline $\begin{array}{l}\text { Paternal height, } \mathrm{cm} \\
\quad<160.1 \\
\geq 160.1\end{array}$ & $\begin{array}{l}165(160-170)^{7} \\
57(39.0) \\
89(61.0)\end{array}$ \\
\hline $\begin{array}{c}\text { Paternal BMI, } \mathrm{kg} / \mathrm{m}^{2} \\
<18.5 \\
18.5-22.5 \\
>22.5\end{array}$ & $\begin{array}{l}23.3(20-25.3)^{8} \\
14(9.5) \\
51(34.9) \\
81(55.5)\end{array}$ \\
\hline
\end{tabular}

${ }^{1}$ All values are $n(\%)$ otherwise indicated, ${ }^{2-8}$ median $\left(\mathrm{Q} 25^{\text {th- }}{ }^{\mathrm{Q}} 75^{\mathrm{th}}\right)$
Table 2. Schoolchildren characteristics and nutritional $\operatorname{status}^{1}(n=146)$

\begin{tabular}{ll}
\hline Variable(s) & $\boldsymbol{n}(\boldsymbol{\%})$ \\
Age, years & $9.9(9.7-10.2)^{2}$ \\
Sex & $77(52.7)$ \\
$\quad$ Female & $69(47.3)$ \\
Male & $26.4(23.2-31.7)^{3}$ \\
Body weight, kg & $130.5(125.8-134.2)^{4}$ \\
Body height, cm & $-1.17(-1.81 ;-0.57)^{5}$ \\
HAZ Z-score & $28(19.2)$ \\
$\quad$ Stunting & $118(80.8)$ \\
Normal & $-0.59(-1.33 ; 0.49)^{6}$ \\
BAZ Z-score & $17(11.6)$ \\
Thin + Severe wasted & $105(71.9)$ \\
Normal & $24(16.4)$ \\
Overweight & \\
\hline${ }^{1}$ All values are presented as $n(\%)$ otherwise indicated, ${ }^{2-6}$ median $\left(\mathrm{Q} 25^{\text {th- }}\right.$ \\
Q75 $\left.^{\text {th }}\right)$
\end{tabular}

\section{Discussion}

In this study, a lower prevalence of stunting schoolchildren was reported, compared to that of students at national levels (2) and those from previous studies $(15,16)$. Although the prevalence of overweight students was slightly higher (16.4\%) than that of students in previous studies $(12.2 \%)(15)$, it was still lower than national levels (2). In the current study, a significant correlation was seen between the parental nutrition and the schoolchildren HAZ scores. Compared to maternal BMIs, paternal BMIs included a stronger correlation with the children HAZ scores. This finding is similar to findings from previous studies, which showed that paternal and maternal nutrition status were significantly correlated with young children $(<7$ years old) nutritional status $(17,18)$. Interestingly, a study reported that maternal nutrition status further contributed to young children nutritional status, compared to that paternal nutrition status did $(19,20)$. The maternal BMI was responsible for the development of children BAZ scores as well as children HAZ scores $(14,21)$ and higher child survival rates within young children (18). Their nutritional status were still determined by the parental nutrition status even within older children or adolescents $(22,23)$. This result revealed that genetic factors from parents previous nutritional status and current environment were transmitted cross-generationally even over three generations (19). However, it is still unclear that to which extent correlations between parental and children anthropometries are originally genetic, epigenetic or phenotypic (17). 
Table 3. Multivariable analysis of the paternal socio-demography and anthropometry with schoolchildren nutritional status ${ }^{1}$ $(n=146)$

\begin{tabular}{|c|c|c|c|c|c|c|c|c|}
\hline \multirow[t]{2}{*}{ Predictors } & \multicolumn{4}{|c|}{$\mathrm{HAZ}^{2}$} & \multicolumn{4}{|c|}{$\mathrm{BAZ}^{3}$} \\
\hline & Unadjusted $\beta^{4}(95 \% \mathrm{CI})$ & $\mathrm{P}$-value & Adjusted $\beta^{5}(95 \% \mathrm{CI})$ & P-value ${ }^{6}$ & Unadjusted $\beta^{4}(95 \% \mathrm{CI})$ & P-value & Adjusted $\beta^{5}(95 \% \mathrm{CI})$ & P-value ${ }^{7}$ \\
\hline \multicolumn{9}{|l|}{ Socio and demography factors } \\
\hline Maternal age, & $0.114(-0.224 ; 0.453)$ & 0.505 & $0.223(-0.203 ; 0.649)$ & 0.303 & $-0.381(-0.862 ; 0.100)$ & 0.120 & $-0.402(-0.995 ; 0.192)$ & 0.183 \\
\hline Maternal educational level & $-0.219(-0.673 ; 0.236)$ & 0.343 & $-0.168(-0.739 ; 0.404)$ & 0.563 & $-0.753(-1.394 ;-0.112)$ & 0.022 & $-1.206(-2.000 ;-0.441)$ & 0.003 \\
\hline Maternal employment & $-0.181(-0.644 ; 0.282)$ & 0.441 & $-0.265(-0.727 ; 0.196)$ & 0.258 & $-0.274(-0.936 ; 0.289)$ & 0.416 & $-0.214(-0.856 ; 0.428)$ & 0.510 \\
\hline Paternal age & $-0.083(-0.496 ; 0.330)$ & 0.691 & $-0.175(-0.651 ; 0.301)$ & 0.469 & $-0.326(-0.915 ; 0.263)$ & 0.276 & $-0.056(-0.719 ; 0.607)$ & 0.867 \\
\hline Paternal educational level & $-0.285(-0.651 ; 0.080)$ & 0.125 & $-0.082(-0.549 ; 0.385)$ & 0.730 & $-0.168(-0.695 ; 0.358)$ & 0.529 & $0.412(-0.237 ; 1.062)$ & 0.211 \\
\hline Number of children & $-0.046(-0.438 ; 0.346)$ & 0.818 & $-0.087(-0.497 ; 0.322)$ & 0.675 & $-0.312(-0.871 ; 0.248)$ & 0.273 & $-0.128(-0.698 ; 0.442)$ & 0.658 \\
\hline \multicolumn{9}{|l|}{ Anthropometric factors } \\
\hline Maternal BMI & $0.383(0.036 ; 0.730)$ & 0.031 & $0.367(0.009 ; 0.724)$ & 0.044 & $0.702(0.210 ; 1.194)$ & 0.005 & $0.926(0.428 ; 1.423)$ & 0.001 \\
\hline Paternal BMI & $0.427(0.094 ; 0.759)$ & 0.012 & $0.419(0.075 ; 0.762)$ & 0.017 & $0.138(-0.348 ; 0.625)$ & 0.575 & $0.079(-0.399 ; 0.557)$ & 0.744 \\
\hline
\end{tabular}

Another interesting finding, the low BAZ score, is linked to the maternal low education level $(<9$ years of schooling). Similarly, Bernardo and Vasconcelos (2012) reported that overweight status of 2826 children aged 7-14 years old was inversely associated to high maternal education level (22). Maternal literacy is reported to be independently associated to children weight (24). in 2012, Srivastava et al. demonstrated that schoolchildren from an urban slum area in India were at higher risks of malnutrition if mothers had lower schooling years (12). A study on under five-year-old children in Bangladesh showed that upgrading parental education levels is needed for improving children nutritional status (WAZ) (21). Educated parents, particularly mothers, are important for the successful practice of healthy diets in children. Since parents are responsible for purchasing and preparing foods at homes, it can affect children food preferences $(25,26)$. Chong et al. (2017) reported that the more educated parents, the greater children fruit intakes (27). Educated parents can be good role models for their children, having better parenting styles that can influence their children to have better eating habits $(25,28,29)$. As a summary, these findings reveal the importance of good parental nutrition status and literacy that contribute to children nutritional status at school age. However, the current study did not include other potential parameters such as household hygiene and sanitation practices. It was suggested that the hygiene and sanitation conditions were similar within the households in the study area. Another limitation of the present included the small sample size due to the missing parental estimation of their anthrophometric values.

\section{Acknowledgement}

We would like to express our deepest gratitude to schoolteachers, students and parents, who participated in this study. Our sincere thanks to public health service officers for their continuous supports. We gratefully acknowledge Mrs. Rosalina Nugraheni Wulan Purnami, Master of Education from Lembaga Bahasa dan Budaya (Language and Cultural Board) Universitas Esa Unggul for revising English structure and grammar of this manucript.

\section{Funding/Support}

This study was funded by a Research Grant of KEMENRISTEKDIKTI (Ministry of Research and Technology and Higher Education, Indonesia) No. 020/KM/PNT/2018.

\section{Financial disclosure}

The authors declare no competing interests.

\section{References}

1. Kementerian Kesehatan Republik Indonesia. Buku Saku Pemantauan Status Gizi Tahun 2017. retrieved from http://sehatnegeriku.kemkes.go.id/baca/umum/20180125/3 424539/buku-saku-hasil-pemantauan-status-gizi-psgtahun-2017/

2. Republic Indonesia National Institute of Health Research and Development. Riset Kesehatan Dasar. Kementerian Kesehatan Republik Indonesia. 2013;

3. World Health Organization. Nutrition Landscape Information System (NLIS). Ctry Profile Indic Interpret Guide Nutr Landsc Inf Syst NLIS Geneva WHO. 2010;

4. Haile D, Nigatu D, Gashaw K, Demelash H. Height for age $\mathrm{Z}$ score and cognitive function are associated with Academic performance among school children aged 8-11 years old. Arch Public Health. 2016;74(1):17.

5. Martins VJ, Florêncio TMT, Grillo LP, Maria do Carmo $\mathrm{PF}$, Martins PA, Clemente APG, et al. Long-Lasting 
Effects of Undernutrition. Int J Environ Res Public Health. 2011;8(6):1817.

6. Ruel MT, Alderman H. Nutrition-sensitive interventions and programmes: how can they help to accelerate progress in improving maternal and child nutrition? Lancet Lond Engl. 2013 Aug 10;382(9891):536-51.

7. Destyana RM, Angkasa D, Nuzrina R. Hubungan Peran Keluarga dan Pengetahuan Ibu Terhadap Pemberian ASI di Desa Tanah Merah Kabupaten Tangerang. Indonesia J Hum Nutr. 2018;5(1):41-50.

8. Alderman H, Headey DD. How Important is Parental Education for Child Nutrition? World Dev. 2017 Jun;94:448-64.

9. Bogale TY, Bala ET, Tadesse M, Asamoah BO. Prevalence and associated factors for stunting among 6-12 years old school-age children from a rural community of Humbo district, Southern Ethiopia. BMC Public Health. $2018 ; 18$.

10. Rafael Novella. Parental Education, Gender Preferences and Child Nutritional Status: Evidence from Four Developing Countries [Internet]. Institute for Social and Economic Research; 2013. Available from: https://www.iser.essex.ac.uk/research/publications/workin g-papers/iser/2013-06

11. Bhavsar S, Hemant M, Kulkarni R. Maternal and environmental factors affecting the nutritional status of children in Mumbai urban slum. Int J Sci Res Publ. 2012;2(11):1-9.

12. Srivastava A, Mahmood SE, Srivastava PM, Shrotriya VP, Kumar B. Nutritional status of the school-age children-A scenario of urban slums in India. Arch Public Health. 2012;70(1):8.

13. Leni Sri Rahayu. Associated of Height of Parents with Changes of Stunting Status from 6-12 months to 3-4 years. Universitas Gadjah Mada; 2011.

14. Bernardo C de O, Pudla KJ, Longo GZ, de Vasconcelos F de A. Factors associated with nutritional status of 7-10-yearold schoolchildren: sociodemographic variables, dietary and parental nutritional status. Rev Bras Epidemiol. 2012;15(3):651-61.

15. Angkasa D, Sitoayu L, Jus' at I. Length of paternal education is associated with height-for-age of school children in rural area of Sepatan Timur-Tangerang. GIZI Indonesia. 2018;41(1):27-38.

16. Sandjaja S, Budiman B, Harahap H, Ernawati F, Soekatri M, Widodo $\mathrm{Y}$, et al. Food consumption and nutritional and biochemical status of 0 . 5-12-year-old Indonesian children: the SEANUTS study. Br J Nutr. 2013;110(S3): S11-20.

17. Pomeroy E, Wells JC, Cole TJ, O'Callaghan M, Stock JT. Relationships of maternal and paternal anthropometry with neonatal body size, proportions, and adiposity in an
Australian cohort. Am J Phys Anthropol. 2015;156(4):625-36.

18. Subramanian S, Ackerson LK, Smith GD, John NA. Association of maternal height with child mortality, anthropometric failure, and anemia in India. Jama. 2009;301(16):1691-701.

19. Murrin CM, Kelly GE, Tremblay RE, Kelleher CC. Body mass index and height over three generations: evidence from the Lifeways cross-generational cohort study. BMC Public Health. 2012;12(1):81.

20. Tigga PL, Sen J. Maternal Body Mass Index Is Strongly Associated with Children-Scores for Height and BMI. J Anthropol. 2016;2016.

21. Talukder A. Factors associated with malnutrition among under-five children: an illustration using Bangladesh demographic and health survey, 2014 data. Children. 2017;4(10):88.

22. Bernardo $\mathrm{C}$ de $\mathrm{O}$, Vasconcelos $\mathrm{F}$ de $\mathrm{AG}$ de. Association of parents' nutritional status, and sociodemographic and dietary factors with overweight/obesity in schoolchildren 7 to 14 years old. Cad Saude Publica. 2012;28:291-304.

23. D'Avila GL, Müller RL, Gonsalez PS, Vasconcelos F de AG de. The association between the nutritional status of the mother and the frequency and location of and company during meals and overweight/obesity among adolescents in the city of Florianópolis, Brazil. Rev Bras Saúde Materno Infant. 2015;15(3):289-99.

24. Akseer N, Bhatti Z, Mashal T, Soofi S, Moineddin R, Black RE, et al. Geospatial inequalities and determinants of nutritional status among women and children in Afghanistan: an observational study. Lancet Glob Health. 2018;6(4):e447-59.

25. Meriska I, Pramudho K, Murwanto B. Perilaku Sarapan Pagi Anak Sekolah Dasar. J Kesehat. 2016;5(1).

26. Nicklas T, Hayes D. Position of the American Dietetic Association: nutrition guidance for healthy children ages 2 to 11 years. J Am Diet Assoc. 2008;108(6):1038-44.

27. Chong KH, Lee ST, Ng SA, Khouw I, Poh BK. Fruit and Vegetable Intake Patterns and Their Associations with Sociodemographic Characteristics, Anthropometric Status and Nutrient Intake Profiles among Malaysian Children Aged 1-6 Years. Nutrients. 2017;9(8):723.

28. Centers for Disease Control and Prevention. Parent engagement: Strategies for involving parents in school health. 2012.

29. Hermina $\mathrm{H}$, Afriansyah $\mathrm{N}$, Jahari $\mathrm{AB}$. Efek Intervensi Pendidikan Berbasis Sekolah Terhadap Tingkat Pengetahuan Tentang Pencehagan Kegemukan Di Antara Anak-Anak Usia 9-10 Tahun Di Kota Bandung. Penelit Gizi Dan Makanan J Nutr Food Res. 2008;31(2). 